differing from case to case in its intensity, duration and period of onset, can manifest itselt in the most varied groups of 'factors' showing different degrees of 'linkage.' Prof. Huxley says that he does not know what I mean by calling a unit-factor a 'change.' A unit-factor can only be defined and has always been defined by its deviation from the type: that is what I meant by calling it a change.

Prof. Huxley refers to the attempts of Stresemann to account for specific differences between birds on the basis of supposititious mendelising mutations. Stresemann is not the only Mendelian who has attempted this futile task: no good systematist known to me will have anything to say to it, and if readers of NATURE wish to convince themselves of the utter bankruptcy of all such efforts, I recommend them to read the latest and most elaborate of them by Goldschmidt ("Untersuchungen zur Genetik der geographischen Variation," Arch. f. mikr. Anat. u. Entw.-Mech., vol. IoI, I924), in which he deals with the geographical races of Lymantria dispar. After trying in vain to account for his results by assuming (pace Prof. Huxley) Mendelian factors, he is driven back to the assumption of maternal and paternal (!) cytoplasmic influences, and even then does not arrive at a satisfactory solution. He thinks it could perhaps be done by assuming 'modifying factors' (Morgan's patent), but deems such a procedure beneath his dignity. Really, when Prof. Huxley says that Mendelian factors are not 'assumed' one doubts if he realises the meaning of words.

The central fact of biology is adaptation: its central problem is the origin of this adaptation, and until Prof. Huxley recognises this he will continue to flounder in a quagmire of imaginary ' factors,' the number of which will require continual augmentation, as Nature exhibits herself more and more unwilling to be comprised within the narrow formulæ of the geneticists. Really, the top-heavy structure already evolved in the imagination of these gentlemen reminds us of nothing so much as the Ptolemaic conception of the heavens "with cycle and epicycle scribbled o'er," which preceded the views of Kepler and Galileo. E. W. MACBRIDE.

Imperial College of Science and Technology,

South Kensington, London, S.W.7.

THE purpose of my letter published in NATURE ot January $\mathrm{I} 6$, p. 86, was to support, by an example, Prof. MacBride's view that mutations that appear together have some common developmental cause. From Prof. Huxley's letter it seems that the term 'linkage-group' is to be used only if this cause be unknown, when the hypothesis that the characters are associated because their factors are in the same chromosome is less easily disproved.

\section{TATE REgan.}

\section{The Palæolithic Drawing of a Horse from} Sherborne, Dorset.

In Nature of February 13, p. 233, Mr. C. J. Bayzand describes how his leg was pulled by certain boys of Sherborne School (for whose conduct, on their behalf, I wish to apologise to him) with respect to the finding of this inscribed bone.

As I probably know most about the circumstances of the find, I may be allowed to state the facts.

In, if I remember rightly, September I9II, among the new boys who visited the school museum for the first time were A. Cortesi and P. C. Grove, who asked where they could obtain fossils like those in the museum. I directed them to a certain quarry where, as it was being worked, they could find ammonites, etc. In this quarry, on a heap of broken stone, which the workmen told me had come from the opening to an adjacent fissure, still visible, where the rock was much broken, Cortesi, in the presence of Grove (who died in the War), picked up, among other things, a bone, which he handed to the latter, asking if it was a fossil. Grove said "No"; but in giving it back he noticed a drawing upon it. So Cortesi took it to his boarding-house, where in the evening it was examined and thought little of; but when Cortesi was about to throw it into the fire he was stopped by Jefferson (then a boy who had been a year in the school), as stated by him in a recent letter to the headmaster, which I am permitted to send for publication. The bone was accordingly brought to me for inspection, and afterwards given to the school museum by Cortesi.

That two new boys should have made such a discovery was, as any public school boy will understand, not looked upon favourably by many of the older boys, and very soon sides had been taken, for and against, and as "fama viret eundo," the latter party soon changed the locality of the find to a town refuse heap, and would-be recruits were shown how Cortesi must have drawn it, though this was not very effective, for he could not draw "for nuts," as boys say, and the Town Council of Sherborne burned their refuse and do not allow inhabitants to keep horse bones on their premises till they are as brittle as this one.

Eighteen months later the quarrymen broke into a narrow cave forming the lower part of the same fissure, and it was then evident that the heap on which the bone was found was composed of the debris from the quarrying away, some years before, of the entrance to this cave, which pointing south-west was situated near the summit of a short narrow valley, now dry from the working back of some of the Somerset streams draining the low land between Sherborne and Glastonbury and the Mendips, and in which, lower down, we have discovered remains of the mammoth and woolly rhinoceros.

Cortesi was always very jealous for his find to be attributed to himself alone, so it is improbable that any one else at Sherborne drew it, and he certainly could not himself. As a hoax on a master, a new boy in a public school, with all his troubles before him and without for some years any privacy, would scarcely think of hoaxing masters he knew nothing about; in fact, Cortesi's letter to the headmaster disposes of anything of that kind.

I have done my best to unravel the mystery of its production, if it is a 'fake,' and I have come to the conclusion, which I hope Prof. Sollas will accept, that it was not manufactured at Sherborne School. Like Mr. Bayzand, I always felt its similarity to Sir W. Boyd Dawkins' Creswell Crag specimen must raise doubts; but since I, as in duty bound, submitted it to the inspection of the members of the Geological Society, my doubts have been somewhat allayed and I have placed my trust and confidence in them, seeing that I am not in a position to be able to express an opinion myself. May I therefore, in conclusion, ask some member of that learned society to explain how they got over this difficulty of similarity to the Creswell Crag inscribed bone? R. Elliot Steel.

Stalbridge, Dorset, February 18.

Copy of Part of the Letter of Mr. E. A. Ross Jefferson. I7 Kensington Palace Mansions, De Vere Gardens, W.8, I 2.2 .26

Dear Headmaster-Perhaps I may be able to throw some light on the "Palæolithic Bone." Cortesi 